\title{
Symptomatic huge diaphragmatic hernia
}

\author{
Valerio Pontecorvi, Lorenzo Dioscoridi, ${ }^{\circledR}$ Aurora Giannetti, Massimiliano Mutignani
}

Azienda Socio Sanitaria Territoriale Grande Ospedale Metropolitano Niguarda, Milano, Italy

\section{Correspondence to} Dr Lorenzo Dioscoridi, dioscoridi.lorenzo@virgilio.it

Accepted 8 March 2019

\section{DESCRIPTION}

The present images refer to a 54-year-old patient with cholangitis due to biliary stones.

He underwent distal oesophagectomy and total gastrectomy with Roux-en-Y reconstruction for

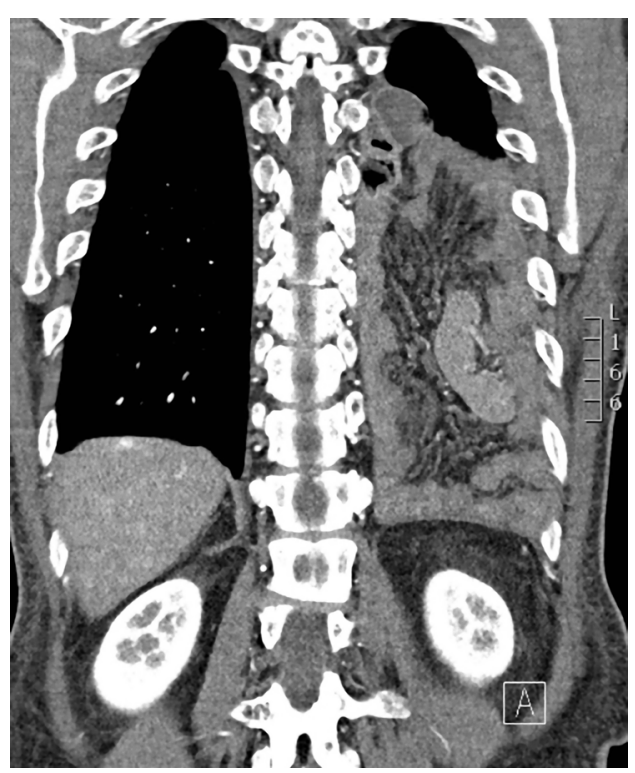

Figure 1 CT scan (coronal view) showing the herniation of the small bowel occupying almost all of the left hemithorax.

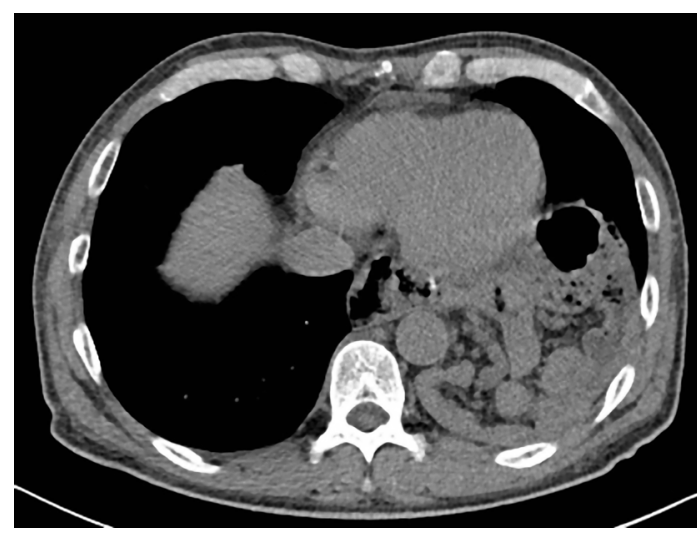

Figure 2 CT scan (axial view) with the evidence of the large diaphragmatic defect along with the mesenteric vessels.

\section{Patient's perspective}

In the end, I was more worried for the hernia than for the biliary stones. It scared me a lot. I would like to thank the Niguarda Hospital for taking care of me.

\section{Learning points}

- Incidental huge diaphragmatic hernias in adults are rare occurrences.

- Huge diaphragmatic hernia is a rare cause of endoscopic retrograde cholangiopancreatography failure.

a tumour of oesophageal-gastric junction 5 years before.

An endoscopic retrograde cholangiopancreatography was attempted but it failed because of the impossibility to access the duodenal pouch due to abnormal rounds of the scope caused by a suspected bowel's hernia in the thorax.

A CT scan (figures 1 and 2) was then performed, and it showed the presence, in retrocardiac position, of a massive diaphragmatic herniation of the small bowel, ${ }^{12}$ along with mesenteric vessels, which reached the apex of the left hemithorax.

This condition is completely asymptomatic, and the patient is now scheduled for preoperative evaluation.

Contributors VP wrote the paper and found the images. LD had the idea of the case report and revised the paper. AG revised the images and wrote the key highlights. MM revised the workpiece.

Funding The authors have not declared a specific grant for this research from any funding agency in the public, commercial or not-for-profit sectors.

Competing interests None declared.

Patient consent for publication Obtained.

Provenance and peer review Not commissioned; externally peer reviewed.

\section{REFERENCES}

1 Chaturvedi A, Rajiah P, Croake A, et al. Imaging of thoracic hernias: types and complications. Insights Imaging 2018;9:989-1005.

2 Sandstrom CK, Stern EJ. Diaphragmatic hernias: a spectrum of radiographic appearances. Curr Probl Diagn Radiol 2011;40:95-115. 
Copyright 2019 BMJ Publishing Group. All rights reserved. For permission to reuse any of this content visit https://www.bmj.com/company/products-services/rights-and-licensing/permissions/

BMJ Case Report Fellows may re-use this article for personal use and teaching without any further permission.

Become a Fellow of BMJ Case Reports today and you can:

- Submit as many cases as you like

- Enjoy fast sympathetic peer review and rapid publication of accepted articles

Access all the published articles

- Re-use any of the published material for personal use and teaching without further permission

For information on Institutional Fellowships contact consortiasales@bmjgroup.com

Visit casereports.bmj.com for more articles like this and to become a Fellow 